\title{
Pengaruh Implementasi Akuntansi Lingkungan terhadap Kinerja Perusahaan
}

\section{Authors:}

Ade Irva Nursamsiah

Akhmad Lutfi ${ }^{2}$

Farisha Eva Apriani ${ }^{3}$

Ida Farida Adi Prawira ${ }^{4}$

Affiliations:

1,2,3,4 Program Studi Akuntansi, Fakultas Pendidikan Ekonomi dan Bisnis, Universitas Pendidikan Indonesia,

Bandung, Indonesia

Corresponding Author:

Ade Irva Nursamsiah

Emails:

1'adeirvan@ student.upi.edu

2akhmad.lutfi72@gmail.com

${ }^{3}$ farishaeva@gmail.com

4ida.farida@upi.edu

Article History:

Received : October 7, 2019

Revised : December 10, 2019

Accepted : December 16, 2019

How to cite this article: Nursamsiah, A. I., Lutfi, A., Apriani, F. E., \& Prawira, I. F. A. (2019). Pengaruh Implementasi Akuntansi Lingkungan terhadap Kinerja Perusahaan. Organum: Jurnal Saintifik Manajemen dan Akuntansi, 2(2), 73-83. doi: https://doi.org/10.35138/organu $\underline{\text { m.v } 2 \mathrm{i} 2.57}$

\section{Journal Homepage:} ejournal.winayamukti.ac.id/ind ex.php/Organum

\section{Copyright:}

(C) 2019. Published by Organum: Jurnal Saintifik Manajemen dan Akuntansi. Faculty of Economics and Business. Winaya Mukti University.
Abstract. This study aims to determine the effect of the implementation of environmental accounting on company performance through analysis of various impacts on company performance, such as increasing costs and decreasing corporate profits, improving company performance, reducing performance damage that often resembles precision and even the impact that shows habits on company performance. The method used in this study is library research. From this study, it could be concluded that environmental accounting had an impact on company performance. The research implication of this study for the development of science is as a material consideration for companies in implementing environmental accounting as a solution to overcome environmental problems.

Keywords: Implementation of environmental accounting; company performance.

Abstrak. Penelitian ini bertujuan untuk mengetahui pengaruh implementasi akuntansi lingkungan terhadap kinerja perusahaan. Melalui analisis, akuntansi lingkungan memiliki dampak yang beragam terhadap kinerja perusahaan. Dampak tersebut antara lain dapat meningkatkan biaya dan menurunkan laba perusahaan, meningkatkan kinerja perusahaan, berkurangnya kerusakan kinerja yang sering menyerupai presisi, dan dampak yang menunjukkan kebiasan pada kinerja perusahaan. Metode yang digunakan dalam penelitian ini adalah jenis penelitian kepustakaan (library research). Berdasarkan penelitian yang telah dilakukan, dapat disimpulkan bahwa akuntansi lingkungan berdampak pada kinerja perusahaan. Implikasi penelitian ini bagi perkembangan ilmu pengetahuan yaitu sebagai bahan pertimbangan bagi perusahaan dalam menerapkan akuntansi lingkungan sebagai solusi mengatasi permasalahan lingkungan.

Kata kunci: Implementasi akuntansi lingkungan; kinerja perusahaan.

\section{Pendahuluan}

$\mathrm{P}$ ersoalan mengenai lingkungan saat ini, semakin mendapatkan perhatian dan dianggap sebagai isu yang penting. Bagaimana tidak, banyak kasus-kasus kerusakan lingkungan yang terjadi secara tidak sadar dampak atas kerusakan lingkungan mulai kita rasakan saat ini. Mulai banyak seruan-seruan mengenai pentingnya menjaga kelestarian lingkungan, namun hal tersebut seakan tidak berpengaruh justru kerusakan lingkungan makin banyak terjadi. Kerusakan lingkungan yang terjadi berkaitan dengan dampak operasi perusahaan, perlu adanya alat kontrol dan sistem tata kelola 
mengenai dampak kerusakan lingkungan yang diakibatkan operasi perusahaan. Akuntansi lingkungan dianggap sebagai solusi terbaik dalam mengatasi masalah kerusakan lingkungan. Akuntansi lingkungan merupakan bentuk pertanggungjawaban perusahaan atas pengelolaan dampak kerusakan lingkungan yang diakibatkan oleh operasi perusahaan. Namun, penerapan akuntansi lingkungan juga bukan tanpa masalah, masih banyak yang perlu dibenahi dalam penerapannya. Kurangnya kesadaran individu dan masyarakat, dalam hal ini dinilai sebagai penyebab kurang maksimalnya penerapan akuntansi lingkungan. Seperti yang terjadi di Indonesia, pembuangan air limbah dari satu industri atau penebangan hutan yang menyimpang selalu menjadi sorotan tajam. Masalah lingkungan dengan adanya pencemaran limbah misalnya, banyak perusahaan-perusahaan telah diberhentikan operasionalnya karena masalah lingkungan yang dicemarkan oleh perusahaan tersebut. Sebagai contoh, isu tentang pencemaran limbah oleh PT Indorayon beberapa tahun lalu di Porsea Sumatra Utara yang berdampak dengan diberhentikannya operasional perusahaan oleh pemerintah karena adanya permasalahan lingkungan dan masalah masyarakat sekitar industri. Isu lainnya berkaitan dengan beberapa perusahaan kertas di Riau yang mendapat protes dari masyarakat setempat sehubungan dengan permasalahan limbah industri dan pencemaran lingkungan. Belum lagi persoalan PT Lapindo Brantas di Sidoarjo dengan lumpur yang tiada henti-hentinya mengakibatkan kerusakan lingkungan dan menelantarkan ribuan masyarakat sekitar, yang sampai hari ini belum juga terselesaikan (Riyadi, 2018).

Aktivitas manusia diakui sebagai pendorong utama dalam perubahan lingkungan global (Russell, Milne, \& Dey, 2017). Adapun menurut pendapat lain mengatakan bahwa akuntansi dan pelaporan lingkungannya sangat penting, akuntansi lingkungan perlu bekerja sebagai alat untuk mengukur efisiensi ekonomi dari kegiatan konservasi lingkungan dan efisiensi lingkungan dari kegiatan bisnis perusahaan secara keseluruhan. Dampak lingkungan yang merugikan dari pembangunan ekonomi telah menjadi masalah perhatian publik yang besar di seluruh dunia. Tampaknya perhatian yang lebih besar ini dapat menyebabkan peningkatan biaya dan karenanya dapat menurunkan laba (Magara et al., 2015). Selain itu, akuntansi juga memiliki dampak positif seperti meningkatkan kinerja perusahaan dalam pengembangan sistem penetapan biaya lingkungan yang telah diartikulasikan dengan baik untuk menjamin atmosfer perusahaan bebas konflik yang dibutuhkan oleh manajer dan pekerja untuk produktivitas maksimum (Cna et al., 2013).

Ditemukan pula dampak negatif dari adanya aktivitas manusia terhadap lingkungan seperti adanya dampak global (perubahan iklim, penipisan ozon, pencemaran laut dan sungai, dan spoliasi hutan), regional (hasil dari kecelakaan industri, polusi air, dan polusi udara), serta juga dampak lokal yang mengakibatkan dampak besar bagi sosial dan juga lingkungan, namun ketidakseimbangan lokal ini bisa diatasi dengan benar dan diakui oleh otoritas, dapat dibatasi, dianalisis, dan dihilangkan dengan keputusan menyatu dengan kebijakan lingkungan (Dascalu et al., 2010).

Namun, dalam jurnal lain juga disampaikan bahwa jika dilihat dari perspektif akuntansi sosial dan kinerja lingkungan, konsep laba konvensional menunjukkan bias dalam pengukuran kinerja (Iqbal et al., 2013). Selain itu, (Mcnellis, 2013) menyampaikan bahwa kerusakan kinerja yang sering menyerupai presisi menjadi berkurang. Seperti kurangnya skeptisisme catatan klien, kurang konservatisme, dan ketergantungan yang lebih besar pada pekerjaan sebelumnya tentu ini menjadi 
perhatian besar terkait dengan profesionalisme dalam bekerja. Sehingga, dengan fenomena tersebut peneliti merasa terkait untuk melakukan penelitian dan mengkaji dampak kinerja yang ditimbulkan oleh akuntansi lingkungan.

Kesadaran atau kemampuan untuk bertindak secara menyeluruh dan tepat merupakan salah satu dari lima besar peningkatan kinerja yang paling luas dan dapat dianggap sebagai ciri-ciri kepribadian. Selain itu, disposisi yang telah terbukti mengurangi efek kelelahan kerja dan penarikan niat dalam lingkungan akuntansi adalah sifat tahan banting. Hal tersebut terbukti pada individu yang memiliki kemampuan bawaan untuk memahami dan mengelola situasi di bawah tekanan. Selain itu, konstruksi hati nurani dan ketangguhan memiliki relevansi yang substansial dalam perjanjian dengan kinerja tugas efektif akurat terhadap penyelesaian (yaitu tingkat efektivitas dan keakuratan dalam menyelesaikan tugas) dalam lingkungan akuntansi, namun pemeriksaan sifat-sifat bersama ini adalah jalan yang relatif tidak ada dari literatur akuntansi terbaru. Dengan demikian, studi saat ini memperluas penyelidikan sifat tahan banting dalam akuntansi lingkungan dengan mempertimbangkan pengaruhnya, ketika disandingkan dengan hati nurani, pada kinerja tugas akuntansi. Dalam penelitian ini juga dijelaskan bahwa studi mengedepankan kesadaran sebagai prediktor positif yang konsisten dari kinerja, beberapa studi mendokumentasikan hubungan negatif antara kesadaran dan kinerja. Dengan menyoroti peningkatan kinerja tugas dan deteksi kesalahan, yang berimplikasi pada investigasi penipuan dan risiko, hasilnya memberikan bukti lebih lanjut tentang kesesuaian dari kepribadian yang kuat dalam mengelola stressor situasional akuntansi publik (Mcnellis, 2013).

Adapun konten dan konteks akuntansi lingkungan beserta akademisi praktisi akuntansi memiliki hubungan kembar dan hidup berdampingan sebagai dasar kapasitas inovasi terhadap alasan untuk menilai kapasitas yang inovatif pada kinerja lingkungan organisasi dan akuntabilitas terkait (Burritt, 2012). Pemerintah daerah pula telah didorong untuk menciptakan sistem manajemen yang tepat untuk mendukung lingkungan perencanaan dan pembuatan kebijakan dan melibatkan semua sektor masyarakat setempat untuk memenuhi tujuan lingkungan, karena mekanisme dalam menerapkan pembangunan berkelanjutan di tingkat lokal dan pemerintah daerah memiliki peran penting (Qian, Burritt, \& Monroe, 2011). Dengan meningkatnya kepentingan data lingkungan dapat memperburuk kekhawatiran tentang penyajian dan pengungkapan akuntansi yang layak digunakan untuk mencapai keberhasilan dalam melaksanakan strategi lingkungan di perusahaan (Alewine \& Stone, 2011). Selain itu juga, perusahaan dan pemerintah mulai mengkhawatirkan dampak operasional perusahaan terhadap lingkungan dan masyarakat, dan individu agar menjadi lebih sadar. Hal ini menjadi fakta bahwa setiap proses operasional memiliki potensi menghasilkan dampak negatif pada sistem ekologi dan sosial (Setthasakko, 2010). Selain itu juga, terdapat masalah lingkungan internasional seperti standar emisi, pengelolaan limbah, polusi udara dan air, perubahan iklim, ekstraksi sumber daya yang dapat habis, bahan bakar nabati, penghematan energi, keanekaragaman hayati, penggurunan (desertification), kehutanan, pertanian, penggunaan lahan, peternakan, ketahanan pangan, populasi, kemiskinan, urbanisasi, transportasi, sekuritas karbon, El Nino, ramah lingkungan teknologi, dan sistem produksi (Negash, 2012). Sehingga memperkuat alasan peneliti untuk mengkaji lebih dalam apakah akuntansi lingkungan berperan secara efektif dalam kinerjanya dalam setiap permasalahan yang ada pada setiap daerah ataupun negara. 


\section{Kajian Literatur}

1. Voluntary/Discretionary Disclosure
Theory

Voluntary/discretionary disclosure theory menjelaskan bahwa perusahaan memiliki dorongan untuk mengungkapkan lebih banyak hal-hal yang baik mengenai perusahaan (good news) untuk membedakannya dari perusahaan lain yang memiliki hal-hal yang buruk (bad news), dengan tujuan untuk memberi keuntungan bagi perusahaan itu sendiri. Kinerja lingkungan yang baik adalah good news bagi perusahaan sehingga perusahaan dengan kinerja lingkungan yang baik akan terdorong untuk mempublikasikan kepada investor dan stakeholder lainnya. Hal tersebut dilakukan dengan cara mengungkapkan lebih banyak informasi lingkungan perusahaan secara sukarela. Informasi yang diungkapkan dapat berupa strategi, kebijakan, aktivitas, dan kinerja itu sendiri, serta pengeluaran yang berkaitan dengan lingkungan. Pengungkapan lebih banyak dan luas mengenai hal-hal tersebut melalui pengungkapan secara sukarela tidak akan dilakukan oleh perusahaan yang memiliki kinerja lingkungan yang buruk. Perusahaan yang lingkungan kinerjanya buruk akan memilih untuk "diam" atau membatasi pengungkapan lingkungannya agar stakeholder tidak dapat mendeteksi kondisi yang sebenarnya. Dengan demikian, voluntary/discretionary disclosure theory memprediksi adanya pengaruh positif kinerja lingkungan terhadap pengungkapan informasi lingkungan (Clarkson, Li, Richardson, \& Vasvari, 2008).

\section{Teori Perusahaan - Adam Smith}

Dalam teori perusahaan Adam Smith yang menyatakan bahwa perusahaan memiliki satu tujuan yaitu untuk memenuhi keinginan pemegang saham dengan menghasilkan keuntungan. Namun, laba perusahaan kemungkinan tidak dapat dicapai apabila lingkungan perusahaan bisnis dalam beroperasi diabaikan. Sebuah perusahaan yang mengakomodasi pendekatan Triple Bottom Line (kinerja sosial, ekonomi dan lingkungan) berkontribusi terhadap pembangunan berkelanjutan (Cna et al., 2013).

\section{Teori Konservatisme}

Teori ini mendefinisikan konservatisme sebagai prinsip kehatihatian dalam pelaporan keuangan dan perusahaan tidak terburu-buru dalam mengakui dan mengukur aktiva dan laba serta segera mengakui kerugian dan hutang yang mempunyai kemungkinan yang terjadi. Penerapan prinsip ini mengakibatkan pilihan metode akuntansi ditujukan pada metode yang melaporkan laba atau aktiva yang lebih rendah serta melaporkan hutang lebih tinggi. Dengan demikian, pemberi pinjaman akan menerima perlindungan atas risiko menurun (downside risk) dari neraca yang menyajikan aset bersih dan laporan keuangan yang melaporkan berita buruk secara tepat waktu (Haniati \& Fitriany, 2010). Sehingga dapat dikatakan bahwa teori konservatisme dengan pilihan metode akuntansi ini akan meningkatkan kualitas laba serta kualitas kinerja karena mencegah perusahaan untuk membesarbesarkan laba dan membantu pengguna laporan keuangan dengan menyajikan laba yang tidak overstated.

\section{Akuntansi Lingkungan}

Akuntansi lingkungan muncul pada tahun 1970-an sebagai hasil dari peningkatan kesadaran lingkungan dan keprihatinan tentang kesejahteraan sosial dan lingkungan (Khalid, Lord, \& Dixon, 2012).

Bagian akuntansi keuangan dari akuntansi lingkungan sudah tersedia melalui laporan tahunan, laporan keberlanjutan dan media pelaporan lainnya, begitupun informasi akuntansi manajemen terkait dengan operasi biasanya dianggap internal dan rahasia (Hussain, Halim, \& Bhuiyan, 2016). 
AICPA mendefinisikan akuntansi lingkungan sebagai akuntansi yang di dalamnya terdapat identifikasi, pengukuran dan alokasi biaya lingkungan, yang biaya-biaya lingkungan ini diintegrasikan dalam pengambilan keputusan bisnis, dan selanjutnya dikomunikasikan kepada para stakeholders.

Environmental Accounting adalah jenis akuntansi yang memasukkan biaya dan manfaat tidak langsung dari aktivitas ekonomi, seperti dampak lingkungan dan konsekuensi kesehatan dari perencanaan dan keputusan bisnis (Cohen \& Robbins, 2011:190).

Akuntansi lingkungan, ketika ditangani dengan baik dapat memberikan manfaat besar bagi individu dan perusahaan. Manfaat tersebut antara lain:

- Hal ini dapat meningkatkan omzet bagi perusahaan karena meningkatnya citra perusahaan dan produk.

- Akuntansi lingkungan dapat membuat saham perusahaan lebih menarik bagi investor karena peningkatan citra perusahaan atau produk dan peringkat risiko lingkungan.

- Akuntansi lingkungan dapat menjamin akses dan persyaratan yang lebih baik dari lembaga pemberi pinjaman karena insiden risiko lingkungan yang menguntungkan.

- Penghitungan lingkungan memastikan kepatuhan dengan undang-undang lingkungan yang pada gilirannya akan meminimalkan eksposur terhadap kerugian finansial di masa depan yang timbul dari insiden lingkungan.

- Akuntansi Lingkungan membawa peningkatan dalam profil perusahaan sebagai akibat dari peningkatan dalam bidang tanggung jawab lingkungan.
- Akuntansi Lingkungan dapat menyebabkan penemuan baru karena organisasi dapat mendaur ulang apa yang sebelumnya dianggap limbah untuk menciptakan produk baru (Adediran \& Alade, 2013).

5. Kinerja

a. Kinerja Keuangan

Kinerja keuangan umumnya digunakan sebagai indikator kesehatan keuangan perusahaan selama periode waktu tertentu. Kinerja keuangan suatu perusahaan dapat diukur dalam berbagai cara yang berbeda termasuk keuntungan, mengukur pengembalian, pertumbuhan pangsa pasar, pengembalian investasi, pengembalian ekuitas dan likuiditas (Magara et al., 2015).

b. Kinerja Lingkungan

Kinerja lingkungan adalah salah satu dari banyak ukuran penting keberhasilan bisnis dan biaya lingkungan adalah salah satu dari banyak jenis biaya yang dikeluarkan oleh bisnis karena menyediakan barang dan jasa kepada pelanggan mereka. Biaya dan kinerja lingkungan pantas mendapat perhatian manajemen karena alasan berikut:

- Banyak biaya lingkungan dapat dikurangi atau dihilangkan secara signifikan sebagai akibat dari keputusan bisnis, mulai dari perubahan operasional dan rumah tangga, hingga investasi dalam teknologi proses lebih baik, hingga mendesain ulang proses/produk.

- Biaya lingkungan, penghematan biaya potensial dapat dikaburkan dalam akun overhead atau diabaikan. Melalui hal ini akan menghasilkan informasi biaya yang salah dan keputusan dan pelaporan manajerial yang buruk.

- Banyak perusahaan telah menemukan bahwa biaya lingkungan dapat diimbangi 
dengan menghasilkan pendapatan melalui penjualan limbah, produk sampingan atau tunjangan polusi yang dapat ditransfer, atau lisensi teknologi bersih.

- Pengelolaan biaya lingkungan yang lebih baik dapat menghasilkan peningkatan kinerja lingkungan dan manfaat signifikan bagi kesehatan manusia serta keberhasilan bisnis.

- Memahami biaya lingkungan dan kinerja proses dan produk dapat mempromosikan penetapan biaya dan harga produk yang lebih akurat dan dapat membantu

- Perusahaan dalam merancang proses, produk, dan layanan yang lebih disukai lingkungan untuk masa depan.

Keunggulan kompetitif dengan pelanggan dapat dihasilkan dari proses, produk, dan layanan yang dapat ditunjukkan lebih disukai secara lingkungan (Adediran \& Alade, 2013).

\section{Metode Penelitian}

Dalam makalah ini, peneliti
menggunakan jenis penelitian
kepustakaan (library research), yaitu
serangkaian kegiatan yang berkenaan
dengan metode pengumpulan data
pustaka. Studi kepustakaan (library
research) adalah serangkaian kegiatan
yang berkenaan dengan metode
pengumpulan data pustaka, membaca dan
mencatat serta mengolah bahan
penelitiannya.

Dalam penelitian ini, peneliti menggunakan model pendekataan content analysis (kajian isi), penelitian ini bersifat pembahasan yang mendalam terhadap isi suatu informasi tertulis atau tercetak dalam media massa. Analisis ini biasanya digunakan pada penelitian kualitatif. Content analysis (kajian isi) secara umum diartikan sebagai metode yang meliputi semua analisis mengenai isi teks, tetapi di sisi lain analisis isi juga digunakan untuk mendeskripsikan pendekatan analisis khusus.

Selain itu metode yang penulis gunakan dalam penelitian ini adalah deskriptif analisis. Di mana metode ini berfungsi untuk mendeskripsikan atau memberikan gambaran terkait obyek dari macam-macam dampak yang ditimbulkan dari akuntansi lingkungan

Penelitian ini dibuat dengan mengkaji kembali data yang bersumber dari data sekunder yaitu data yang diperoleh lewat pihak lain, tidak langsung diperoleh oleh peneliti dari subjek penelitiannya. Dalam studi ini data sekundernya adalah artikel internasional yang mendukung penulis untuk melengkapi isi serta interpretasi jurnal dari sumber data primer. Dalam hal ini, sumber data sekunder berupa tulisantulisan yang sudah mencoba membahas mengenai beberapa pemikiran tentang pengaruh implementasi akuntansi lingkungan terhadap kinerja perusahaan dan literatur-literatur yang relevan dengan penilitian ini.

Pencarian data diawali dengan masuk ke Google, dengan penulisan kata kunci "akuntansi lingkungan" sehingga didapatkan 15.400.000 artikel terkait. Kemudian artikel tersebut dipersempit dengan kata kunci jurnal internasional dan menghasilkan 939.000 artikel. Setelah itu hasil tersebut disempitkan kembali dengan tema artikel terkait yang akan kita ambil seputar macam-macam dampak yang disebabkan oleh akuntansi lingkungan sehingga mendapatkan hasil 341.000 artikel. Belum selesai sampai disitu, kami membatasi artikel tersebut dengan tahun terbit dari setiap jurnal dengan batasan tahun 2009 sampai 2019 dengan mendapatkan hasil 22.300 artikel. Setelah hasil tersebut didapat, selanjutnya diuji pada website beallisist.weebly.com (n.d.) untuk mendapatkan data jurnal internasional yang bereputasi, melalui pengujian tersebut didapatkan hasil 54 artikel bereputasi. Kemudian pada langkah akhir diambil beberapa sampel 
artikel yang cocok dan sesuai dengan tema yang dikaji, sehingga didapatkan dan diambil 30 artikel untuk diteliti. Dari ke 30 artikel yang kami dapatkan, semua bersumber dari beberapa jurnal internasional seperti: Emerald, Elsevier, Scopus, Taylor and Francis, dan Scientific Research.

\section{Hasil dan Pembahasan}

Berdasarkan penelitian yang kami lakukan terdapat beberapa faktor akuntansi lingkungan yang berdampak terhadap kinerja perusahaaan baik itu dampak positif ataupun negatif. Seperti pada sumber berikut dikatakan bahwa langkah-langkah kekerasan memiliki korelasi positif dan signifikan dengan kepuasan tugas, namun sebaliknya hubungan antara hati nurani dan kepuasan tidak signifikan. Korelasi ini memberikan bukti perbedaan antara kedua sifat kepribadian serta aktivasi sifat tahan banting pada tugas rekonsiliasi bank. Dengan demikian, hasilnya konsisten dengan anggapan bahwa subjek yang kuat mampu menemukan yang lebih dalam tingkat kepentingan dalam kegiatan rekonsiliasi (Mcnellis, 2013). Dalam bidang lain, akuntansi lingkungan menjadi standar pelaporan terintegritas yang ditargetkan untuk organisasi di semua ukuran di Indonesia berbagai sektor, swasta, pemerintahan, dan nonpemerintahan. Melalui penelitian akademik transdisipliner yaitu inti dari lingkungan yang bergerak dari akuntabilitas kinerja menuju kelestarian lingkungan, menghasilkan kesimpulan bahwa strategi untuk peneliti masa depan dalam kinerja lingkungan akuntansi banyak dan beragam (Burritt, 2012).

Akuntansi lingkungan ini juga memiliki dampak dalam peningkatan kuantitas informasi dalam SBSC lima perspektif (keuangan, pelanggan, proses, belajar, dan masyarakat) yang dapat meningkatkan peluang informasi, kelebihan daripada SBSC empat perspektif (keuangan, pelanggan, proses, dan belajar), dengan menambahkan yang kelima perspektif scorecard ini dapat dianggap sebagai tingkat kesulitan tugas yang lebih tinggi, dan peningkatan kesulitan mungkin cukup untuk mengurangi peningkatan kinerja. (Alewine \& Stone, 2011).

Dari sumber lainnya ditemukan juga bahwa akuntansi lingkungan manajerial menyediakan cara komprehensif untuk menggabungkan pertimbangan lingkungan ke dalam pengambilan keputusan bisnis. Dimasukkannya internal biaya lingkungan dalam accounting-nya akan membantu perusahaan dalam bekerja untuk memaksimalkannya profitabilitas saat ini. Perusahaan selanjutnya dapat dibimbing dalam memaksimalkan keuntungan jangka panjangnya dengan memperhitungkan biaya lingkungan eksternal, terutama sejauh mungkin diperlukan untuk menginternalisasi biayabiaya ini di masa depan. Adopsi metode ini dapat membantu organisasi dalam posisi kompetitif yang lebih kuat dalam kaitannya dengan perusahaan tertentu (Dascalu et al., 2010). Selain itu, terdapat juga faktor lain yang berpengaruh pada kinerja di akuntansi lingkungan ini seperti EMA (Environmental Management Accounting) yang bertindak sebagai mediator pada hubungan antara strategi lingkungan dan kinerja lingkungan. Dikatakan bahwa tidak ada perbedaan yang signifikan antara peringkat PROPER (Program Penilaian Peringkat Perusahaan dalam Pengelolaan Lingkungan Hidup) dan persepsi responden terhadap kinerja lingkungan, yang berarti bahwa hasil model utama sudah memiliki ketahanan yang baik. Temuan ini menegaskan bahwa tidak ada bias sistematis mengganggu hasil ini untuk dua ukuran kinerja lingkungan. Semakin banyak strategi perusahaan itu berfokus pada lingkungan, semakin besar pengaruh ini terhadap penggunaan EMA (Environmental Management Accounting).

Dalam pengungkapan informasi, penggunaan EMA (Environmental 
Management Accounting) sebagai aset tidak berwujud telah menguntungkan perusahaan dengan memberikan informasi pada kegiatan operasional mereka, terutama yang berkaitan dengan lingkungan dan hasil kinerja lingkungan yang baik. Serta strategi lingkungan dapat memengaruhi kinerja lingkungan baik secara langsung maupun tidak langsung melalui penggunaan EMA (Environmental Management Accounting). Bukti empiris menunjukkan bahwa ada pengaruh positif dan signifikan antara strategi lingkungan dan penggunaan EMA (Environmental Management Accounting), yang, pada gilirannya, dapat meningkatkan kualitas perusahaan (Solovida \& Latan, 2017). Dikatakan pula bahwa akuntansi berhasil mengungkapkan efisiensi unit ekonomi dalam tanggung jawab sosialnya, terutama dalam pengendalian pencemaran lingkungan, seperti yang terjadi sebelumnya dalam mengungkapkan informasi yang sesuai dan cukup tentang efisiensi kinerja ekonomi atau keuangan, tentu akan memainkan peran penting untuk mengubah perilaku pembuat keputusan dan orang-orang yang tertarik pada kesatuan ekonomi dan meningkatkan keuntungan mereka ketika mereka mengambil keputusan yang tepat (Alqtish \& Qatawneh, 2017). Selain itu, karena pengungkapan informasi lingkungan secara sukarela menjadikan perusahaan besar cenderung melaporkan lebih banyak informasi lingkungan dalam laporan tahunan mereka daripada bisnis skala menengah; dan pengungkapannya, cenderung lebih kualitatif daripada kuantitatif meskipun ada fakta bahwa ada hubungan yang signifikan antara akuntansi lingkungan dan kinerja perusahaan (Adediran \& Alade, 2013).

Tetapi pendapat lain menyatakan kinerja lingkungan memiliki pengaruh positif yang tidak signifikan terhadap pengungkapan informasi lingkungan. Hubungan yang tidak signifikan ini terkait dengan pengungkapan informasi lingkungan yang tidak dipantau sehingga manajemen perusahaan bebas menggunakan laporan informasi diskresioner (Iqbal et al., 2013). Akuntansi lingkungan masih juga menghadapi sejumlah masalah, mengenai kurangnya dukungan informasi, personil khusus serta tidak adanya model akuntansi internasional proporsional. Dalam beberapa tahun terakhir, upaya untuk pertumbuhan sistem informasi lingkungan telah mengarah pada penciptaan sistem administrasi proporsional (Sistem Manajemen Lingkungan) yang menghadapi masalah terkait dengan perawatan data lingkungan yang rumit (Moorthy \& Yacob, 2013).

Berdasarkan penelitian terdahulu lainnya, (Cna et al., 2013) menyatakan adanya dampak dari biaya lingkungan terhadap kinerja perusahaan minyak di negara-negara Delta Niger di Nigeria. Dengan mengikuti analisis deret waktu yang terperinci, temuan ini mengungkapkan bahwa biaya lingkungan dalam sektor minyak Nigeria memiliki dampak signifikan pada kinerja perusahaan. Dengan demikian, hal ini menjelaskan tingkat perubahan kinerja perusahaan yang sangat tinggi. Sehingga biaya pengembangan masyarakat, biaya pengelolaan sampah, serta kesehatan karyawan dan biaya keselamatan telah secara signifikan memengaruhi kinerja perusahaan di sektor minyak Nigeria. Sedangkan menurut (Adediran \& Alade, 2013), pada penelitiannya menunjukkan bahwa ada hubungan negatif yang signifikan antara akuntansi lingkungan dan Return on Capital Employed (ROCE) dan Earnings Per Share (EPS) dan hubungan positif yang signifikan antara akuntansi lingkungan dan margin laba bersih dan dividen per saham. Berdasarkan hal ini direkomendasikan bahwa pemerintah harus memberikan kredit pajak kepada organisasi yang mematuhi undang-undang lingkungannya dan bahwa pelaporan lingkungan harus dibuat wajib di Nigeria untuk 
meningkatkan kinerja organisasi dan negara secara keseluruhan.

Penerapan akuntansi lingkungan yang diteliti oleh Iqbal et al., (2013) menunjukkan bahwa akuntansi lingkungan belum mampu memengaruhi nilai perusahaan karena di beberapa perusahaan, penerapan akuntansi lingkungan diterapkan karena diwajibkan oleh pemerintah, yang membuktikan rendahnya kesadaran pihak manajemen. Sedangkan, kinerja lingkungan pada penelitian ini ternyata mampu memengaruhi nilai perusahaan. Dan dari keseluruhan temuan review yang diteliti oleh Hussain, Halim, \& Bhuiyan (2016) menyatakan bahwa akuntansi lingkungan adalah masalah vital untuk pembangunan berkelanjutan terutama untuk berkonsentrasi pada pajak lingkungan, biaya lingkungan, menilai jasa ekosistem, biaya karbon dioksida, biaya polusi air, dan memastikan keberlanjutan pendapatan dari memimpin dengan cara pembangunan berkelanjutan.

\section{Kesimpulan}

Dari hasil dan pembahasan pada penelitian ini, dapat disimpulkan bahwa akuntansi lingkungan atau enviromental accounting memiliki dampak positif dan negatif. Secara positif akuntansi lingkungan dapat memberikan dampak yang bagus terhadap kinerja. Dengan adanya dampak yang bagus bagi kinerja ini memberikan dampak yang bagus pula terhadap kinerja lingkungan dan secara signifikan berhubungan positif dengan keuangan organisasi perusahaan. Sehingga peran akuntan menjadi peran utama dalam menilai kinerja akuntansi lingkungan.

Dalam beberapa kasus perusahaan yang menerapkan akuntansi lingkungan berdampak positif pada kinerja lingkungan sehingga perusahaan mendapatkan keunggulan kompetitif dan meningkatkan nilai tambah. Selain itu dengan menerapkan salah satu konsep akuntansi lingkungan yaitu akuntansi manajemen lingkungan (EMA) akan membantu perusahaan dalam bekerja untuk memaksimalkan profitabilitas dan keuntungan jangka panjang serta membantu manajemen dalam pengambilan keputusan.

Namun, dengan adanya akuntansi lingkungan tersebut tidak dipungkiri juga memberikan dampak negatif bagi perusahaan. Hal ini bisa diketahui pada fenomena yang diteliti, diketahui masih belum bisa merubah kinerja yang berhubungan dengan lingkungan. Pada beberapa perusahaan penerapan akuntansi lingkungan belum mampu memengaruhi nilai perusahaan dikarenakan penerapan akuntansi lingkungan menjadi suatu yang diwajibkan oleh peraturan (keterpaksaan) membuktikan kurangnya kesadaran pihak manajemen sehingga mengakibatkan tidak maksimalnya penerapan akuntansi lingkungan tersebut. Pada kasus lain akuntansi lingkungan berdampak negatif dikarenakan tidak dipantaunya informasi mengenai akuntansi lingkungan sehingga akuntansi lingkungan berdampak negatif.

\section{Daftar Pustaka}

Adediran, S. A., \& Alade, S. O. (2013). The Impact of Environmental Accounting on Corporate Performance in Nigeria. European Journal of Business \& Management, 5(23), 141-152. Diakses dari https://www.iiste.org/Journals/index .php/EJBM/article/view/7485/7809

Alewine, H. C., \& Stone, D. N. (2011). How Does Environmental Accounting Information Influence Attention and Investment?. International Journal of Accounting \& Information Management, 21(1), 22-52. doi: https://doi.org/10.1108/1834764131 $\underline{1299731}$

Alqtish, A. M., \& Qatawneh, A. M. (2017). The Impact of Accounting on Environmental Costs to Improve the Quality of Accounting 
Information in the Jordanian Industrial Companies. International Journal of Business and Management, 12(6), 104-110. doi: https://doi.org/10.5539/ijbm.v12n6p 104

Beall, Jeffrey. (n.d.). Diakses dari http://beallisist.weebly.com/

Burritt, R. L. (2012). Environmental Performance Accountability: Planet, People, Profits. Accounting, Auditing \& Accountability Journal, 25(2), 370-405. doi: https://doi.org/10.1108/0951357121 $\underline{1198791}$

Clarkson, P. M., Li, Yue., Richardson, G. D., \& Vasvari, F. P. (2008). Revisiting the Relation between Environmental Performance Disclosure: An Empirical Analysis. Accounting, Organizations, and Society, 33(4-5), 303-327. doi: https://doi.org/10.1016/j.aos.2007.0 $\underline{5.003}$

Cna, A. I. M. S. K., Etale, L. M., \& Frank, B. P. (2013). The Impact of Environmental Cost on Corporate Performance: A Study of Oil Companies in Niger Delta States of Nigeria. Journal of Business \& Management, 2(2), 1-10. doi: https://doi.org/10.12735/jbm.v2i2p0 $\underline{1}$

Cohen, N., \& Robbins, P. (2011). Green Business: An A-to-Z Guide. California: SAGE Publications Inc. doi:

http://dx.doi.org/10.4135/97814129 $\underline{73793}$

Dascalu, C., Caraiani, C., Lungu, C. I., Colceag, F., \& Guse, G. R. (2010). The Externalities In Social Environmental Accounting, 18(1), 19-30. doi: https://doi.org/10.1108/1834764101 $\underline{1023252}$
Haniati, S., \& Fitriany, F. (2010). 'Pengaruh Konservatisme Terhadap Asimetri Informasi Dengan Menggunakan Beberapa Model Pengukuran Konservatisme', di Purwokerto: Seminar Nasional Akuntansi XIII. Diakses dari https://docplayer.info/29900079-

Pengaruh-konservatisme-terhadapasimetri-informasi-denganmenggunakan-beberapa-modelpengukuran-konservatisme-srihaniati-fitriany.html

Hussain, M. D., Halim, M. S B. A., \& Bhuiyan, A. B. (2016). Environmental Accounting and Sustainable Development: An Empirical Review. International Journal of Business and Technopreneurship, 6(2), 335-350. Diakses dari https://www.researchgate.net/public ation/308708630_Environmental_A ccounting and_Sustainable_Develo pment_An_Empirical_Review

Iqbal, M., Sutrisno, T., Assih, P., \& Rosidi, R. (2013). Effect of Environmental Accounting Implementation and Environmental Performance and Environmental Information Disclosure as Mediation on Company Value. International Journal of Business and Management Invention, 2(10), 55-67. Diakses dari https://ijbmi.org/v2i10(version1).ht $\underline{\mathrm{ml}}$

Khalid, F. M., Lord, B. R., \& Dixon, K. (2012). Environmental Management Accounting Implementation in Environmentally Sensitive Industries in Malaysia. Paper presented on the 6th NZ Management Accounting Conference, in Palmerston North, 22-23 November 2012. Diakses dari https://ir.canterbury.ac.nz/handle/10 $\underline{092 / 7376}$ 
Magara, R., Aming'a, N. N., \& Momanyi, E. (2015). Effect of Environmental Accounting on Company Financial Performance in Kisii County. British Journal of Economics, Management \& Trade, 10(1), 1-11. doi: https://doi.org/10.9734/BJEMT/201 5/19909

Mcnellis, C. J. (2013). The Impact Of Hardiness on Accounting Task Performance. Managerial Auditing Journal, 28(4), 364-380. doi: https://doi.org/10.1108/0268690131 $\underline{1311945}$

Moorthy, K., \& Yacob, P. (2013). Green Accounting: Cost Measures. Open Journal of Accounting, 2(1), 4-7. doi:

https://doi.org/10.4236/ojacct.2013. 21002

Negash, M. (2012). IFRS and Environmental Accounting. Management Research Review, 35(7), 577-601. doi: https://doi.org/10.1108/0140917121 $\underline{1238811}$

Qian, W., Burritt, R., \& Monroe, G. (2011). Environmental Management Accounting in Local Government: A Case of Waste Management. Accounting, Auditing, and Accountability Journal, 24(1), 93128.

doi: https://doi.org/10.1108/0951357111 $\underline{1098072}$

Riyadi, P. (20 Agustus 2018). Green Accounting Berbasis Aspek Berkelanjutan. Kompasiana Beyond Blogging. Diakses dari https://www.kompasiana.com/padla h86933/5b74e6366ddcae1a2748b32 3/green-accounting-berbasis-aspekberkelanjutan?page $=$ all

Russell, S., Milne, M. J., \& Dey, C. (2017). Accounts of Nature and The Nature of Accounts Ecologically Informed Accounting. Accounting,
Auditing, Accountability Journal, 30(7), 1426-1458. doi: https://doi.org/10.1108/AAAJ-07$\underline{2017-3010}$

Setthasakko, W. (2010). Barriers to The Development of Environmental Management Accounting, an Exploratory Study of Pulp and Paper. EuroMed Journal of Business, 5(3), 315-331. doi: https://doi.org/10.1108/1450219101 $\underline{1080836}$

Solovida, G. T., \& Latan, H. (2017). Linking Environmental Strategy To Environmental Performance Management Accounting. Sustainability Accounting, Management and Policy Journal, 8(5), 595-619. doi: https://doi.org/10.1108/SAMPJ-082016-0046 